EPRA International Journal of Economic and Business Review-Peer Reviewed Journal

Volume - 8, Issue -12, December 2020 |e-ISSN: 2347 - 9671| p- ISSN: 2349 - 0187

SJIF Impact Factor (2020): 8.107|| ISI Value: 1.433|| Journal DOI URL: https://doi.org/10.36713/epra2012

\title{
SOCIO-ECONOMIC PROFILE OF PURI DISTRICT OF ODISHA
}

$\begin{gathered}\text { Dr. Kailash Chandra } \\ \text { Mishra }\end{gathered}$
$\begin{gathered}\text { Assistant Prof. of Economics, M. P. C. Autonomous } \\ \text { College, Baripada } \\ \text { Dist-Mayurbhanj-757003, Odisha, India, }\end{gathered}$

Puri district is rich in natural resources. The agro-climatic condition and topography are also favourable for exploitation of natural resources. However, the fragmented holding and insufficient irrigational facilities are the main obstacles for agricultural development. Modern methods of farming, adoption of large scale farm mechanism could not pick up to the desired extent due to the fragmentation of land holdings. Agriculture is the predominant sector but has remained stagnant. On the other hand, there is dearth of industries in the district. Though there is the existence of some small scale and cottage industries in the district, these industries are traditional in nature. They are not equipped with advanced technology. Due to lack of mines and mineral ores, no heavy or large scale industry can be established till date. The district famous for its piligrimage has not earned any industrial or commercial importance. The Sun temple of Konark, famous Jagannath temple and Sea beach of Puri are the main tourist attraction places. Thus tourism is an expanding and vibrant sector. But it is not sufficient to absorb the growing population. To absorb the growing population and for improving the standard of living, large number of employment opportunities has to be created with Government encouragement and Mission Shakti Programme initiatives. The analysis of the socio-economic backdrop of the district presents a gloomy scenario. The district is characterized by low income, mass poverty, higher magnitude of unemployment, low human and social development. The district still primarily depends upon agriculture for livelihood and employment. It is industrially backward with nominal industrial units, poor absorption of labour force, and low level of investment and output. Thus, the district needs a significant change in the direction and content through diversification of the structure of its economy.

KEY WORDS: Puri district, Population, Agriculture, Employment, industry,

\subsection{LOCATION}

Puri is one of the coastal districts of Odisha situated between $19^{\circ} 28^{\prime}$ to $20^{\circ} 10^{\prime}$ North latitude and between $85^{\circ} 9^{\prime}$ to $86^{0} 25^{\prime}$, East longitude. Its boundaries extend in east to Bay of Bengal, in the Northern East to district of Cuttack, in South-West to the district of Khurda and district of Ganjam in its South. The total geographical area of Puri District is
3479 sq. Kms. and is home to $16,98,730$ souls in the year 2011. The district with 2.23 per cent of the state's area and 4.08 per cent of the state's population occupies the twenty first and the ninth ranks respectively among the thirty districts of Odisha. 


\subsection{ADMINISTRATIVE PROFILE}

Puri was the capital of the province of odisha and the headquarters of the Collector, till 1816. In 1816 there was a proposal to remove the headquarters to Jajpur, but it did not get government sanction. In August 1814, a part of the collector's establishment was removed to cuttack, which was again brought back to puri in December. However, the headquarters' was permanently shifted from Puri to Cuttack in 1816. Puri was administered under Cuttack till 1828. Finally, on the $23^{\text {rd }}$ October 1828 , the province was divided into three districts, namely, Balasore, Cuttack and Jagannath, later known as Puri. The district was divided into four subdivisions, namely, Purisadar, Khurda, Nayagarh and
Bhubaneswar in 1959.Thereafter, for a long time, there has been no change in the boundaries of the district

In the year 1993, Khurda, Bhubaneswar and Nayagarh were separated from the district of Puri and became two independent districts namely, Khurda and Nayagarh. The headquarters of Khurda district is Bhubaneswar. Now, with the re-shuffle of boundaries Odisha has 30 districts. The Puri district is now having only one subdivision, seven Tahasils, eleven C.D. Blocks, one municipality, three N.A.Cs and with sixteen police stations. Further, the district has 230 Gram Panchayats and 1635 revenue villages having six assembly constituencies.

\section{Fig 1.1 Map of India showing the location of Odisha}

$\mathrm{N}$

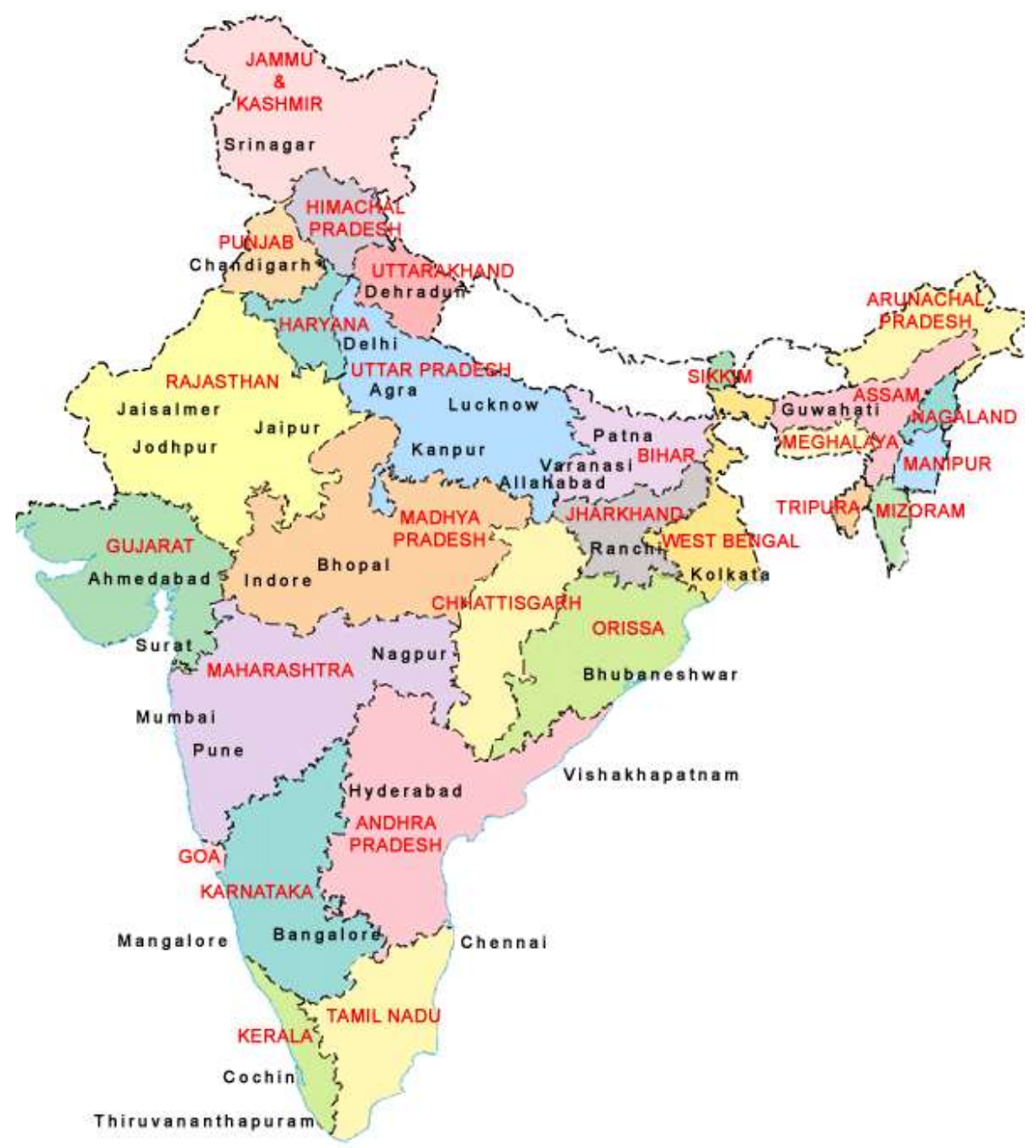


Fig 1.2 Map of Odisha Showing the location of Puri District

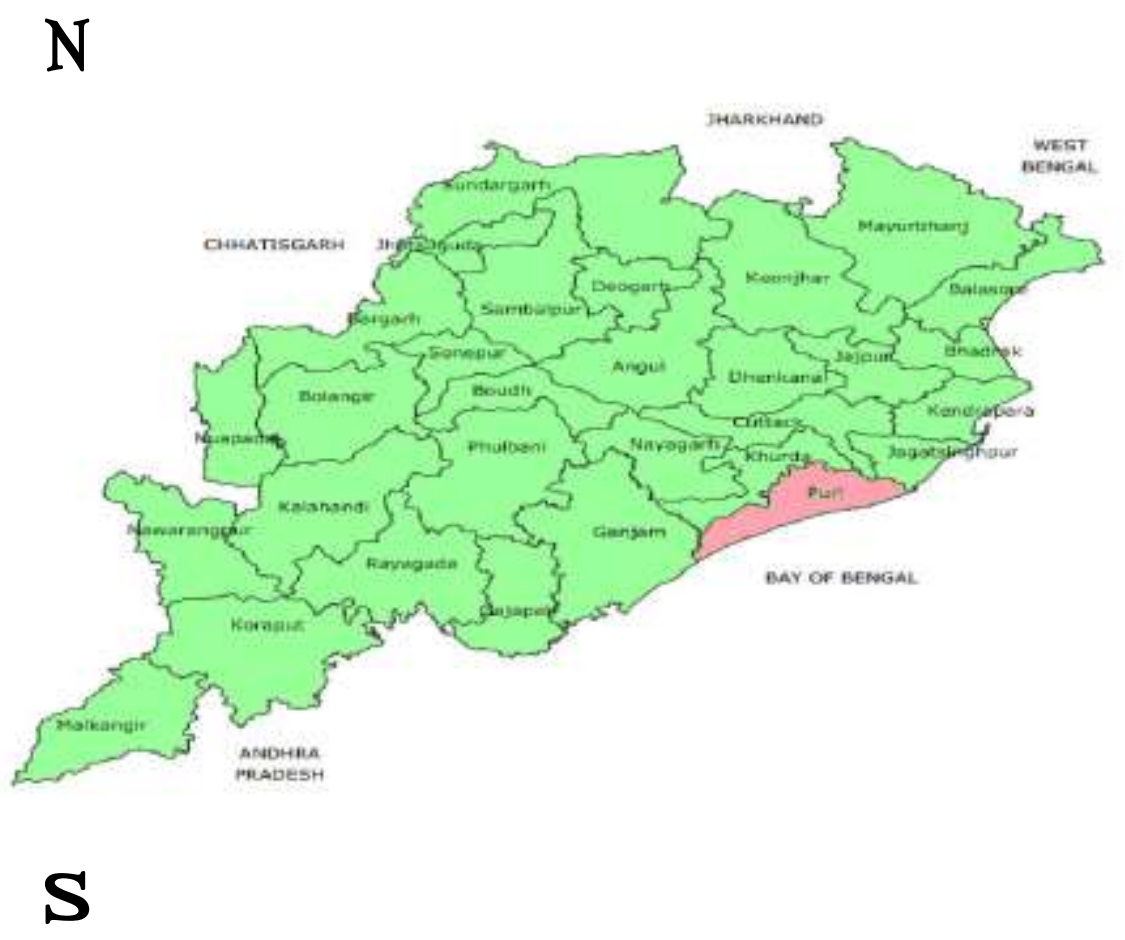

Fig 2.3 Map of Puri District showing the Blocks

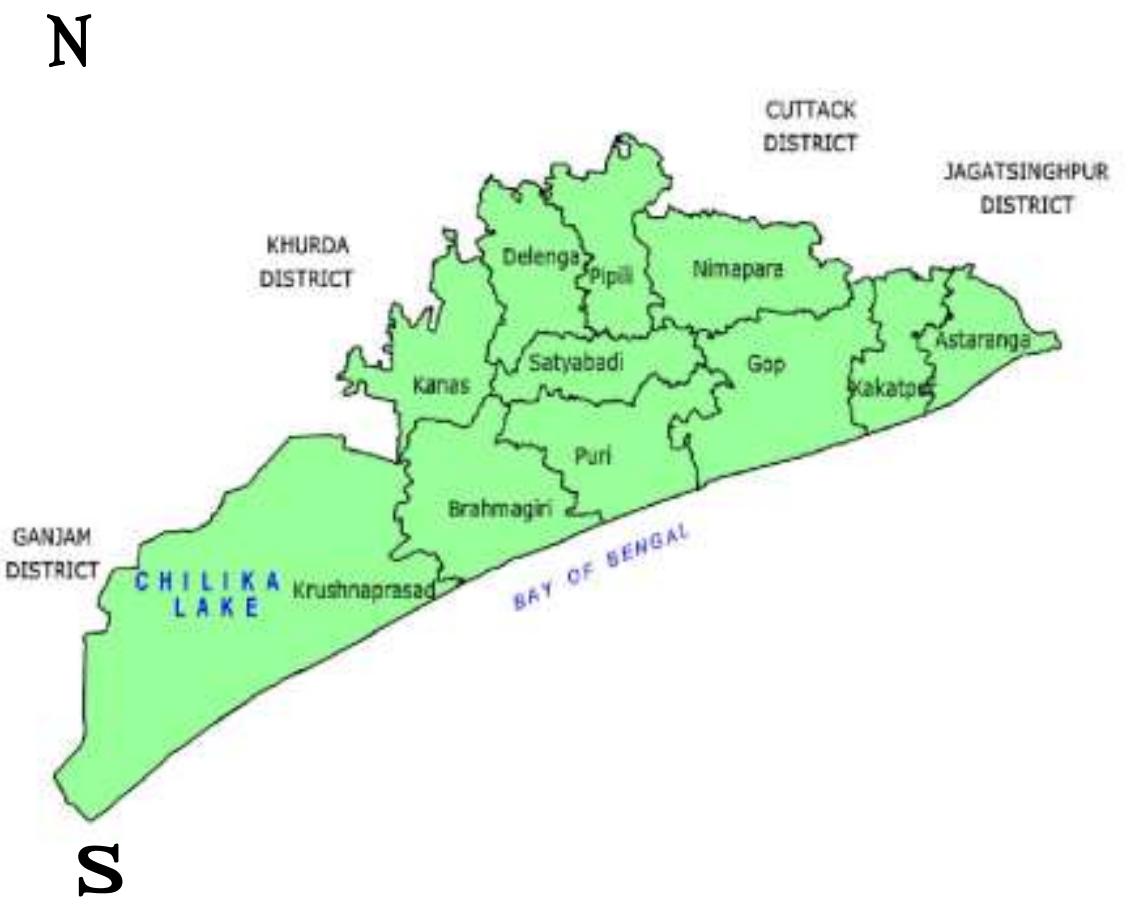




\subsection{TOPOGRAPHY}

The district as a whole is divided into two dissimilar natural divisions, viz. the littoral tract and alluvial tract. This includes blocks of Brahmagiri, PuriSadar, Gop, Astaranga, Satyabadi and Kakatpur falling in the coastal alluvium sub-region and that include blocks of Nimapara, Delanga, Krushna Prasad, Pipili and Kanas falling in the Deltaic alluvium sub region. The district along with the river 'Daya' is flat and alluvial. The littoral tract in fact lies between the alluvial plains and the Bay of Bengal. It assumes the form of a bare belt of sandy ridges which stretches along the seashore for the full length of the district varying from a few hundred metres to $6.5 \mathrm{~km}$. in width. It forms the dividing line between the Chilka lagoon and the ocean. The level of alluvial region is full of villages and rice fields irrigated by a network of canals through which the water of the river Kuakhai, find its way to the sea.

The Coastal alluvium belongs to Coastal Marine Saline and lacustrine saline. A narrow strip of low load along the sea coast is rendered saline by the incursion of tidal water. The saline water comes through the rivulets and cruks which innundates the flat plain lands. The salt is rich with neutral salts of chloride and sulphate of sodium, magnesium, calcium and potassium.

The deltaic deposits are of recent formation and termed as Entisol. The soils are sandy beam to clay loam in texture and soil is acidic to neutral. The soil is generally fertile but soil with low content of nitrogen and phosphorous are also found in the district.

\subsubsection{Climate and Rainfall}

The climate of the district is monsoonic hot humid to subhumid. The deltaic region of the district enjoys a temperative climate all the year round. Normal rainfall of the district is $1550 \mathrm{~mm}$. and the annual rainfall recorded in the year 2014-15 is 1615.1 $\mathrm{mm}$. The cold season is from December to February followed by hot season from March to May. The period from June to September is the monsoon period with October and November constitute post monsoon transition period. The monsoon generally arrives over the district towards the first or second week of June and recedes early in October. July is the rainiest month and the climate is characterised by alternate wet and dry season. Wind is fairly strong in monsoonic months. Relative humidity is generally high throughout the year in the coastal areas. Humidity reaches a maximum of $41 \%$ in cold season and $80 \%$ during the rainy season. Clean sunshine hours fall to as low as $26 \%$ during the rainy season whereas the same attains a value of $80 \%$ during the winter. Fairly strong winds generally blow from northern of north-eastern directions. In summer and monsoonic months, wind are mainly south western and south westernly. Depression and cyclonic storms originate in the Bay of Bengal in the pre-monsoon and post monsoon months and passes through or in the neighbourhood of the district. The storms cause heavy rain and high winds in the district. Thunder storms sometimes occur violently in the pre-monsoon months of May and in October.

\subsubsection{Forest}

Being a coastal district, forest comprises very little of its total geographical area. It is well known that forest plays a vital and important role in the economy and ecology not only of this district but also for the country as a whole. Until recently, there was no consciousness either on the part of the administration or on the part of the society that forests have an intrinsic right to land. Forestry as such was permitted on residual land not required for any other purposes. This led to large scale deforestation throughout the country. Whatever forest was there in Puri was largely deforested owing to indiscriminate leases and large scale encroachments. The damage caused by such providence has been realized somewhat lately. However, the district has the forest area about 137.10 sq. $\mathrm{km}$. covering $3.94 \%$ of total geographical area as on 31.03.2015 The forest area coverage in the district is much below the ideal situation of 30 per cent. Out of the total forest area, $15.66 \mathrm{sq}$. $\mathrm{Km}$. comes under reserve forest, 85.88 sq. $\mathrm{km}$. belongs to demarcated protected forest, 0.51 sq. km. and 35.05 sq. km. are unclassified forest and other forests of Revenue Department respectively. Sri JagannathVanaPrakalpa has been implemented under SGRY Scheme. The district administration has also taken steps for encouraging social forestry through SGSY and other sponsored programme.

Table-1.1

Classification of Forest Area in Puri District

\begin{tabular}{|l|l|c|}
\hline \multicolumn{1}{|c|}{ Sl No } & \multicolumn{1}{|c|}{ Classification of Forest } & Area in SqKms. \\
\hline 1 & Reserve Forest & 15.66 \\
\hline 2 & Demarcated Protected Forests & 85.88 \\
\hline 3 & Un-demarcated Forests & 0.00 \\
\hline 4 & Un classified Forests & 0.51 \\
\hline 5 & Other Forests & 35.05 \\
\hline 6 & Total & 137.10 \\
\hline
\end{tabular}




\subsection{DEMOGRAPHIC DIVERSITIES}

Puri is one of the small districts of Odisha. It accounts for 2.23 per cent of the state's territory and shares 4.08 per cent of the state's population. The total population of Puri district according to 2011 census was $16,98,730$, of whom $8,65,380$ were males and $8,33,350$ females. The district comprises one sub-division, seven tehsils and eleven C.D. Blocks, one municipality, three N.A.Cs and with sixteen police stations. The district has 230 Gram
Panchayats and 1,715 villages having six assembly constituencies. The average density of population according to 2011 census was 488 persons to the square kilometre which is more than the state average of 270. Of the total population of 1,698 thousand, 1,433 thousand persons live in rural areas and the remaining 265 thousand persons live in urban areas. The rural-urban population ratio thus comes to about $7: 1$. The demographic profile is shown in Table-1.2.

Table-1.2

Demographic Profile

\begin{tabular}{|l|l|c|c|}
\hline \multirow{2}{*}{$\begin{array}{c}\text { Sl. } \\
\text { No. }\end{array}$} & \multicolumn{1}{|c|}{ Description } & \multicolumn{2}{|c|}{$\mathbf{2 0 0 1}$} \\
\cline { 3 - 4 } & \multicolumn{1}{|c|}{ Puri } & Odisha \\
\hline 1. & Total Population & $16,98,730(4.08)$ & $4,19,74,218$ \\
\hline 2. & Total male & $8,65,380(4.09)$ & $1,86,60,570$ \\
\hline 3. & Total female & $8,33,350(4.07)$ & $1,81,44,090$ \\
\hline 4. & Decadal Growth(per cent) & 13 & 14 \\
\hline 5. & $\begin{array}{l}\text { Sex Ratio(No. of female per } \\
\text { 1,000 male) }\end{array}$ & 963 & 979 \\
\hline 6. & Density of population & 488 & 270 \\
\hline 7. & Total Literacy Rate(Per cent) & 84.7 & 72.9 \\
\hline 8. & Male Literacy & 90.8 & 81.6 \\
\hline 9. & Female Literacy & 78.3 & 64.0 \\
\hline 10. & Rural Population & $14,33,800(84.4)$ & $3,49,70,562(83.3)$ \\
\hline 11. & Urban Population & 19.14 & $70,03,656(16.7)$ \\
\hline 12 & SC Population(per cent) & 0.36 & 17.1 \\
\hline 13 & ST Population(per cent) & & 22.8 \\
\hline Source- Census of India-2011 & & \\
\hline
\end{tabular}

Figures in Parentheses indicate Percentage of the district

This implies that more than 84 per cent people live in rural areas and around 16 per cent (15.67) live in urban areas. The average density of population, according to the census of 2011 is 488 persons to the square kilometer, which is more than the state average of 270 . The literacy rate of Puri district according to 2011 census is 84.7 per cent which is more than the state rate of 72.9 per cent. Increase in the literacy rate from $77.96 \%$ in 2001 to $84.7 \%$ in 2011 was significant. The male and female literacy rates have gone up to $90.8 \%$ and 78.3 per cent respectively in 2011.

According to 2011 census, Scheduled Castes and Scheduled Tribes population in the district were 3.25 lakh and 0.06 lakh respectively, which is $19.1 \%$ and $0.4 \%$ of the total population of the district. The literacy rate of S.C. and S.T. population in the district was $64.05 \%$ and $58.72 \%$ respectively in 2001 census which was much higher than the state literacy rate. The literacy rate was $42.51 \%$ for SC and $38.94 \%$ for ST in 1991 census. So far as Sex-ratio is concerned 963 female per thousand of male persists. The proportion of population distribution (rural/urban) and literacy are major determinants in any area. Although literacy rate is satisfactory in the district, the concentration of rural population indicates the poor economic condition of the people of the district .The decadal growth rate (2001-2011) of the district population was $13 \%$ as against state growth rate of $14 \%$. Out of total number of workers $(6,21,676)$, marginal workers were $1,71,140$ and rest $4,50,536$ were main workers. The occupational distribution of population in the Puri district is given in table-1.3. 
Table-1.3

Occupational Distribution of Population in Puri District

\begin{tabular}{|l|l|c|c|}
\hline \multicolumn{2}{|c|}{ Type of workers } & $\begin{array}{c}\text { No of persons (in } \\
\text { thousands) }\end{array}$ & \% to Total \\
\hline \multirow{4}{*}{ Main workers } & Cultivators & 172.76 & 27.79 \\
\cline { 2 - 4 } & Agriculture Laborers & 163.94 & 26.37 \\
\cline { 2 - 4 } & House hold industry worker & 25.11 & 4.04 \\
\cline { 2 - 4 } & Other workers & 259.86 & 41.80 \\
\hline Marginal workers & 171.14 & 27.53 \\
\hline Total & 621.67 & 100 \\
\hline
\end{tabular}

Source - Economic survey 2010-11, Government of Odisha.

It is concluded that most of the people living in this district are disadvantageous. In many parts of the district, basic facilities are not available for which they are suffering a lot.

\subsection{LAND UTILISATION PATTERN}

The district has a geographical area of 3479 square kilometer which is 2.23 per cent of the total geographical area of the state. In 2014-15, it is found that the net sown area stood at 139 thousand hectares consisting of 49.97 per cent of the total geographical area (278165 hectares). The Land utilisation Pattern of the district during 2014-15 is shown in Table-1.4.

Table-1.4

Land Utilization Statistics of Puri District

\begin{tabular}{|l|l|c|}
\hline $\begin{array}{l}\text { Sl. } \\
\text { No }\end{array}$ & Purpose of Land use & Area in hectares \\
\hline 1. & Forest area & $4397(1.58)$ \\
\hline 2. & Misc. tree crops \& groves not included in net area sown & $19717(7.09)$ \\
\hline 3. & Permanent pasture and other grazing land & $12535(4.51)$ \\
\hline 4. & Culturable waste & $7944(2.86)$ \\
\hline 5. & Land put to non-agricultural uses & $58564(21.05)$ \\
\hline 6. & Barren and uncultivable lands & $8251(2.97)$ \\
\hline 7. & Current fallows & $16806(6.04)$ \\
\hline 8. & Other fallows & $10950(3.94)$ \\
\hline 9. & Net area sown & $139001(49.97)$ \\
\hline 10. & Total & $278165(100 \%)$ \\
\hline
\end{tabular}

Source - District Statistical Hand Book, 2015, Puri

Note-The estimate excludes Urban area, Reserve forests, Protected forests, Project area, Hill blocks, Villages submerged under rivers and sea.

The above table presents the pattern of land utilization in Puri district. Out of total geographical area of the district, forest covers 4,397 hectares.

Land to the amount of $1,39,001$ hectares belongs to the category of net area sown which is 49.97 per cent of the total area. In Puri, miscellaneous trees \& groves are there in 19,717 hectares which is 7.09 per cent. Land remains in the class of fallow have been measured to the extent of 27,756 hectares in the district which is 9.98 per cent of the total area.

Further, out of the total area, 12,535 hectares are remained as permanent pastures and other grazing land in Puri.

A large chunk of the total geographical area (i.e.58,564 hectares) is put to non-agricultural uses which is 21.05 per cent of the total area. 8,251 hectares (i.e.2.97\%) are treated as barren and uncultivable lands and 7944 hectares (i.e.2.86\%) are treated cultivable waste in Puri district.

\subsubsection{Land Holding Pattern}

The distribution pattern of land holding in Puri district is given in Table-1.5. The agronomic scenario of Puri district is Peculiar in terms of land and land holdings as observed in table-1.5. For better understanding the operational holding is classified into five categories i.e. Marginal, Small, Semimedium, Medium and Large. Land holdings below one hectare are classified under marginal, One to Two hectares under small, Two to Four hectares under semi-medium, Four to Ten hectares under 
medium and above ten hectares under large category. While analysing the area of land holdings against numbers, it shows that in marginal 39.8 per cent of area is acquired by 73.5 per cent of holders, in small 31.5 per cent is acquired by19.3 per cent of holders, in semi-medium 18.7 per cent is acquired by 5.8 per cent of holders and in Medium 8.1 per cent of area is acquired by 1.2 per cent of holders. It reveals lower percentage of land is shared by higher percentage of land holders.
Further, it is found that the average size of holding in Puri district is 0.82 hectares which is less than the state average (i.e. 1.13 hectares) and majority of the land holders average size of holding in the district is 0.45 hectares. From the analysis of landholdings and land operation of Puri, it is revealed that the skewed distribution of landholding is a great obstacle for agricultural development in the district.

Table -1.5

Distribution pattern of Land Holdings in Puri District

\begin{tabular}{|c|c|c|c|}
\hline $\begin{array}{c}\text { Types of operational } \\
\text { Holdings }\end{array}$ & No of holder & Area in hectares & $\begin{array}{c}\text { Average size of } \\
\text { Holdings } \\
\text { (in hectares) }\end{array}$ \\
\hline Marginal(Below 1hectare) & $119280(73.5)$ & $53248(39.8)$ & 0.45 \\
\hline Small(1-2hectare) & $31355(19.3)$ & $42120(31.5)$ & 1.34 \\
\hline Semi-medium(2-4 hectare) & $9492(5.8)$ & $25032(18.7)$ & 2.64 \\
\hline Medium(4-10hectare) & $1980(1.2)$ & $10818(8.1)$ & 5.46 \\
\hline Large(Above 10 hectare) & $150(0.1)$ & $2497(1.9)$ & 16.65 \\
\hline Total & $162257(100)$ & $133715(100)$ & 0.82 \\
\hline
\end{tabular}

Source- Odisha Economic Survey 2010-11

\subsection{AGRICULTURE}

Puri is characterised by rural and agrarian economy. About $70 \%$ of the total population of Puri depends on agriculture. Agriculture is the mainstay of the people of the district. Considering the soil condition, favourable climate, rainfall and cultivable land, Puri district has an ample scope for agriculture. In fact, Agriculture is the prime source of employment and income to people in the district. It is surprising to note that the people in the district still adopt traditional methods of cultivation. Paddy is the Principal crop followed by wheat, ragi, pulses, vegetables, oil seeds, jute and betel-vine. During 2016-17, the total production of paddy was $36,99,496$ quintals. The minor crops cultivated in the district are wheat, ragi, greengram, black gram, horsegram, til, groundnut, mustard, potato, jute, sugarcane etc. During 2016-17, the production of wheat is 750 quintals, ragi is 165 quintals, greengram is 10,507 quintals, blackgram is 27,648 quintals and horsegram is 5,819 quintals. Likewise,the production of til, groundnut, mustard ,potato, and sugarcane are 2.54 quintals, 34,529 quintals, 30 quintals, 52,624 quintals, and 1,33,477 quintals respectively.

During 2016-17, the consumption of chemical fertilizer was 16,533 metric tons and the chemical fertilizers consumed were nitrogenous, phosphatic and potassic types.

As to the irrigation facilities 1,57,904 hectares of potential areas created in the district during the year 2016-17 from all sources. Out of which 89,658 hectares is of potential created during the Khariff and that of 68,246 hectares during the
Rabi showing the Percentage of 47.50 and 36.16 respectively. The Major portion of irrigation is received from the major irrigation provided by Mahanadi Delta- II. Under lift irrigation, 291 numbers of L.I. Points with a capacity of 7,326 hectares have already been handed over to panipanchayats.

Besides non-edible oil is extracted from polang seeds and is exported outside the state for use in chemical industries. Sugarcane and Jute are grown as commercial crops in the district. Cotton and tobacco are also cultivated on a limited scale. Pan is grown on a commercial scale. After meeting the local demand, it is exported outside the district in large quantities. This is mostly found in Chandanpur area of Purisadar block, Kakatpur, and Nimapara.

The main vegetables cultivated in the district are potato, Brinjal, Pumpkin, Onion, garlic, Radish, Cabbage, Cauliflower and Sweet Potato. Potato cultivation is gradually becoming popular as a cash crop.

Basing on good Agro climatic condition, undulating topography of most parts of District, it is an ideal situation for commercial development of a host of plantation and horticulture crops. Fruits like coconut, Banana, Mango, Guava, Cashew, Jack-fruit, Papaya and tamarind are being grown throughout the district. Coconut is one of the important cash crops in this district. The total production of Puri, in fact, accounts for more than 50 per cent of the state's production. Table-1.6 shows the area $\&$ production of different fruits in the district. 
Table-1.6

Area and Production of Fruits

\begin{tabular}{|c|c|c|}
\hline Crops & Area in Hectare & Production in \\
M.T
\end{tabular}

Source- District Statistical Hand Book, Puri, 2017

The Coconut research station at Sakhigopal undertakes research on different aspects of coconut cultivation in Orissa. Coconut varieties from other parts of India and also from outside the country are being put up on trial to know their suitability for cultivation in the local soil and climate. The Research station also undertakes experiments on the application of different manures and fertilisers and control of pests. Besides, quality seedlings are produced from specially selected seed nuts from the plants of the farm attached to the Research Station and also from selected plants of other coconut cultivators. The research station has established two training-cum-demonstration farms located at Konark and Tangi to educate the local cultivators in improved methods of coconut cultivation.

\subsubsection{Animal Husbandry}

Animal resources play a major role in Puri district as about $80 \%$ of its rural households own livestock of one species or the other and earn supplementary income for the family. According to $17^{\text {th }}$ Quinquennial Livestock census 2003, Puri district had a total of $8,54,816$ livestock of which $4,92,326$ were cattle, 31,521 buffalo, 70,555 sheeps, 1,30,831 goats, 2039 pigs and 127544 fowls. There are 15 hospitals \& dispensaries, 28 V.A.S, 90 livestock centres, 68 livestock inspectors, and 61 artificial insemination centres in the district.

The livestock population (according to livestock Census - 2003) is shown in Table-1.7.

Table -1.7

Livestock population of Puri

\begin{tabular}{|l|c|c|}
\hline \multicolumn{1}{|c|}{ Animals } & No. of Animals & \% to Total \\
\hline Cattle & $4,92,326$ & 57.6 \\
\hline Buffaloes & 31,521 & 3.69 \\
\hline Sheep & 70,555 & 8.25 \\
\hline Goats & $1,30,831$ & 15.31 \\
\hline Pigs & 2,039 & 0.24 \\
\hline Fowls & $1,27,544$ & 14.92 \\
\hline Total & $8,54,816$ & 100 \\
\hline
\end{tabular}

Source- District Statistical Hand Book, Puri, 2017.

The local breeds of cattle are generally stunted in growth and are poor in quality. Bullock and Buffaloes are employed in ploughing and pulling carts. Cows and she-buffaloes are maintained for milk purpose. Goats, sheep and pigs are reared for table purpose. In the year 2006-07 the total production of meat in the Puri district was 1877 M.T., out of which 361.07 M.T. sheep meat, 1375.83 M.T. Goat meat and 140.10 M.T. Pig meat. The total milk production in the district in the year 2006-07 was 91.04 thousand metric tonne (TMT) as against the target of 140.04 TMT. There are 219 milk producing cooperative societies in the district with procurement of 30 thousand lt./day on an average.

The production of milk being much less than the actual requirements there is much to be done for dairy development in the district. People in urban areas have to depend upon the unreliable milk men for their supply of milk. Adulterated milk is sold invariably by these milk men inspite of the checks exercised by the authorities. The state govt. has started implementing various schemes for the creation of graded cattle improved progeny particularly crossbreeds animals of exotic species and high yielding varieties. Introduction of this high yielding variety to increase milk production has become popular among the people of this district. The goats, sheep and pigs are reared only for meat. The climatic condition of the district is not congenial to the woolly breed of sheep. The local breed of goat yield very little milk, barely sufficient for their kids.

However, the district possesses considerable livestock assets. Animal husbandry has become a 
major programme because of its potentiality to generate employment and income, both to farming and non-farming households. Lower capital investment and quick return are the factors responsible for making animal husbandry programme popular among the rural families. Agriculture alone can't improve the economic condition of the rural poor because the district which depends upon monsoon for agriculture is affected regularly by flood and cyclone. Therefore, livestock and poultry development schemes have ample scope of development in the district.

\subsubsection{Poultry}

The local poultry birds do not require any special care for rearing and they collect their own food. Being shy layers, these small sized birds are used both for egg production and for table purpose. In order to improve the local breed by crossbreeding with improved varieties and also to attract local people for keeping poultry for profit; poultry firms and poultry units have been started at different parts of the district by the state and Central Governments. In the year 2006-07, the total egg production in the district was 183.09 lakh.

\subsubsection{Fisheries}

Fisheries are important not only for its high unit value but also for improving the rural economy and for providing gainful employment to a large section of the rural population. Puri, the maritime district has a unique advantage of coastal, brackish and riverine eco-system that can support commercially viable aquaculture in a big way. It has vast potential of fisheries resources under inland and brackish water sector. The inland waters like rivers, canals, ponds, swamps, irrigation projects and tanks are the sources of fresh water fish. On the other hand, one of the biggest brackish water lakes situated in Puri district is the Chilika Lake.

The Chilika Lake has an area of 906 sq. $\mathrm{km}$. in summer and $1165 \mathrm{sq} . \mathrm{km}$. in the rainy season. It receives fresh water from the river Daya, one of the deltaic branches of the river Mahanadi, and several small local streams and Nalas. The prosperity of the fisheries of the lake is dependant on the width of this natural mouth of the lake. Fed by fresh as well as saline water, it supports a good brackish water fishery, but most of the important commercial fishes of the lake are of marine origin. Besides the fishes, the lake harbours various types of prawns and crabs of prime economic importance.

The deep sea fishing is done by very few local Oriya fishermen rather Nolias carry out most of the sea fishing in Puri coast. The fishermen of Chilika belong to different castes viz. Keuta, Niari, Kartia, Gokha, Kandara and Tiar who are all Oriyas. The Nolias live on the sea coast.

Besides, the marine potential in the Bay of Bengal, the Chilika Lake provides excellent potential for production of marine fish and production of prawn through brackish water prawn culture.

Fish production during 2016-17 was 39052.07 MT (Metric Tonne) showning an increase of about $3.33 \%$ over 2015-16. Out of total fish production of 39052.07 MT, marine water fish constituted $74.93 \%$ followed by fresh water fish $19.12 \%$ and brackish water fish $5.95 \%$. The production of fish in the district during 2016-17 is given in Table-1.8

Table -1.8

Fish Production in Puri District

\begin{tabular}{|l|c|c|}
\hline \multicolumn{1}{|c|}{ Type of water } & Production of fish in MT & \% to Total \\
\hline Fresh Water & $6,634.05$ & 16.99 \\
\hline Brackish Water & $2,135.02$ & 5.47 \\
\hline Marine Water & $30,283.00$ & 77.54 \\
\hline Total & $39,052.07$ & 100 \\
\hline
\end{tabular}

Source - Directorate of Fisheries, Odisha, Cuttack.

Thus Puri district has a vast marine resource which needs more development by adopting new technology instead of traditional method of fishing. The district has a coast line of $155 \mathrm{kms}$. and about 67,101 fishermen are engaged in the activities. Though, pisciculture is an age-old practice, regular culture on scientific lines was not practiced because technology was not adequately developed and available to fish farmers. To adopt scientific pisciculture through modern technology, financial assistance is necessary.

\subsection{INDUSTRIES AND MINING}

Various industries in cottage sector have flourished in the district since generations. Weaving, pottery, brass and bell-metal work, coir work, processing of bamboo work, salt manufacture, etc. were the most reputed categories of industries. Competition of cheap machine made goods as well as various administrative discriminatory measures adopted by the British destroyed their prosperity. As a result most of these cottage industries are lying in a moribund condition. We get a good picture of the old time industries of the district, from the account given by L.S.S.O'Malley in the Puri District Gazetteer, published in 1908 .

The district, famous for its places of pilgrimage, has not earned any industrial or commercial importance. No heavy or large-scale 
industries have been established so far, mainly because of the lack of proper survey of its mineral resources and industrial potentiality. The growth of different types of industries is shown below.

Table-1.9

Growth of Different Industries in Puri District

\begin{tabular}{|l|c|c|}
\hline \multicolumn{1}{|c|}{ Type of Industries } & No. of Industries & \% to Total \\
\hline Large scale Industries & Nil & 00 \\
\hline Small Scale industries & 200 & 40 \\
\hline Cottage Industries & 300 & 60 \\
\hline Total & 500 & 100 \\
\hline
\end{tabular}

Source - Directorate of industries, Odisha, Cuttack.

Small scale industrial units are gradually coming up mostly in the urban areas of the district. Those industries consuming raw materials available locally are found to have grown at Puri and Sakhigopal. Growth of small scale industries is being emphasised not only because of its potential for generation of employment opportunities but also for its contribution to the output. There were 180 SSI units during 2011-12 went into production with total investment of Rs. 765.63 lakhs and 911 persons were provided employment opportunities. During 201617, 200 small scale enterprises went into production with total investment of Rs. 387.95 lakhs and 799 persons were provided employment opportunities.

Similarly cottage industries were 1974 units during 2001-02 which went into production with total investment of Rs. 474.84 lakhs and 3308 persons were provided employment as compared to 300 cottage industries with total capital investment of Rs. 87.98 lakhs and employment generated to the extent of 300 persons during 2016-17.

Handlooms are a part of rich cultural heritage of the district and handloom products have earned a reputation in and outside the district/ state. It has a tremendous employment potential. For various reasons all powerloom units in the district are either in a sick condition or running on conversion basis. During 2011-12, 1424 looms were made operational and producing 7.49 lakh square metres of cloth with 2,848 person's employment generation. Whereas during 2016-17, 1720 looms were made operational and producing 4.69 lakh square metres of cloth with employment generation to the extent of 2,562 persons.

In the absence of thorough geological survey, it is difficult to comment on the potential mineral wealth of the district which is considered to be poor. At present there is only one working fireclay mine at Jagannath Prasad which feeds the refractory plant at Barang of the Orissa Industries Limited. Besides, as reported, there are occurrences of china-clay and quartzite at different places. Beach sands of the district are having ilmenite and other valuable minerals. But these have not yet been worked on commercial basis. Practically there are no mines in the district. But Laterite, Sand stone, Gravel etc. are quarried for building and road-metalling. The rock, most commonly used for building purpose in the district is laterite.

\subsection{INFRASTRUCTURE}

The availability of adequate infrastructural facilities is a precondition to rapid economic development. All the sectors like primary, secondary and tertiary sectors are heavily dependent on infrastructural facilities for their growth. There are two types of infrastructure - (i) Economic Infrastructure which includes Power/ Electricity, transport, communication and banking (ii) Social infrastructure which includes education and health.

\subsubsection{Power}

Electricity is one of the prime movers of any developed economy. Adequate and reliable availability of electricity is indispensable for sustained growth path. 1,535 numbers of villages have been electrified so far showing an achievement of 97.1 per cent as against the state figure of $76.1 \%$ by the end of the year 2011-12. By the end of the year 2016-17, 1,558 numbers of villages i.e. $97.9 \%$ of the total villages of the Puri district have been electrified.

The total power consumption in the district during 2016-17 was 105.97 million units. Out of this, 59.46 per cent was consumed for domestic and kutirjyoti purposes, 4.27 per cent by the different industries, 2.85 per cent by agriculture and the rest 33.42 percent was utilised for other purposes.

\subsubsection{Transport and Communication}

The progress and prosperity of a country depends much upon the facilities of communication. Puri is relatively one of the fast developing coastal districts of odisha. Prior to independence, most of the roads were un-metalled and un-bridged and are negotiable only in fair-weather. With the change of time, demand for better roads increased for breaking the age-old isolation of many areas of the district, which were mostly inaccessible. Construction of roads and development of road transport were considered very much essential for the economic development. To accelerate this, large amounts were earmarked and spent on the development of roads in the successive plan periods. In the absence of adequate internal rail links, surface roads have 
remained the major means of transport in the district. The total road length of the district was $10,353 \mathrm{kms}$. during 2016-17. The length of roads according to category wise in the district is given below.

Table 1.10

Length of Different Categories of Roads in Puri District.

\begin{tabular}{|l|c|c|}
\hline Sl. No. & Categories of Roads & Length in Kms. in 2006-07 \\
\hline 1. & National Highway & 133 \\
\hline 2. & State Highway & 85 \\
\hline 3. & Major District Roads & 287 \\
\hline 4. & Other District Roads & 24 \\
\hline 5. & Forest Roads & 7282 \\
\hline 6. & Grampanchayat Roads & 59 \\
\hline 7. & Classified Village Roads & 574 \\
\hline 8. & P.S. Roads & 873 \\
\hline 9. & Village Roads & 878 \\
\hline 10. & Urban Roads & 10,353 \\
\hline \multicolumn{2}{|c|}{} \\
\hline
\end{tabular}

At the end of 2016-17, total railway route length in Puri was $42.08 \mathrm{~km}$. and it has 9 railway stations including Puri. The density of railway route length per thousand sq. $\mathrm{km}$. area in the district was around $12.09 \mathrm{~km}$. During 2016-17, 31,122 motor vehicles were on road in the district and it has been increased to 36,293 during 2017-18. Number of motor vehicles per thousand sq. km. Was 10,432 and per thousand population, the same was 24 .

\subsubsection{Post and Telegraphs}

There are 302 post and telegraph offices in the district as on 31.03.2017. Total 302 post and telegraph offices includes 1 head post office, 62 subpost offices and 239 branch post offices in the district to meet the needs of the people. The post and telegraph offices per lakh of population was twenty and area served per post office was 11.52 square $\mathrm{km}$. in the same year in the district. Besides its normal functions which include sale of postage stamps, post cards, envelopes and remittance of money orders, savings bank facilities are also offered to the public at the Head and Sub-Post Offices.

\subsubsection{Market}

Trade and commerce in the district are mainly agro based, forest based and marine based. The chief exports of the district are paddy, rice, jute, fish, dried fish, oil seeds, and coconut \& coir products. The imported commodities are wheat, sugar, fertilizer, grocery, iron and steel goods, agricultural implements, drugs, engineering products, cements, kerosene oil, petroleum products, cloth, readymade garments, electrical goods, spices, automobiles and utensils. The chief commercial centres of the district are Puri, Brahmagiri. Gop, Nimapara, Pipili, Sakhigopal and Chandanpur.

In rural areas, greater part of local trade is carried on at a good number of local markets scattered throughout. These markets, sit on specific days of a week. These markets, though generally not of any great-size, are conveniently situated for the supply of local needs. They also act as centres at which grain is collected for export. The weekly market is most important channels of agricultural marketing. The average distance covered by people to bring commodities to the nearest market centres is $10 \mathrm{~km}$. Merchants from town areas and also from outside the district visit these markets for purchasing goods.

\subsubsection{Banking}

Capital deficiency has been considered as one of the major causes for underdevelopment. In every sector there is a shortage of capital. Indian agriculture is no exception to it. Even when the farmers have got their own land they have to borrow from village money lenders at an exorbitant rate of interest and other stringent terms and conditions to meet the cultivation expenses. However, nationalization of banks followed by introduction of "Lead Bank Scheme" and Micro Finance brought about a remarkable change in this situation. The opening of commercial bank and RRBs in the remote areas and provision of micro-finance freed the vulnerable sections from the clutches of traditional money lenders and played a significant role in improving the living standard of the people in rural India.

The first institutional Banking organisation came into existence in 1908 with the inauguration of the Puri Bank at Puri. During the post second world war period, five more banks, namely the Darjeeling Bank, the Bank of Calcutta, The Tripura Modern Bank, the East India Commercial Bank and the Kubera Bank were established in the district but all 
these banks were liquidated prior to 1948 due to mismanagement and lack of investment.

Besides, the Government has amended the Orissa Cooperative Societies Act so that people can avail loans easily. After independence, due to nationalisation of various commercial banks and initiation of RRBs, the banking network has been increased. There are 59 reporting offices of public sector banks in the district as on 31.03.2017. Similarly RRBs reporting offices were 42 in 2017 and all the scheduled commercial banks reporting office stood at 101 in the same period. The total deposits of all scheduled commercial banks were Rs. 95,100 lakh and credit to the extent of Rs. 65,900 lakh. So the credit deposit ratio in the district as on 31.03.2017 is 69.30 per cent. The UCO Bank is the lead bank of the district. Puri Gramya Bank (renamed as Nilachal Gramya Bank) is the regional bank of Puri district. In addition to it, The United Puri-Nimapara Central Cooperative Bank and The Puri Urban Cooperative Bank are functioning in this district. The total number of branches of central cooperative banks in the district stood at 12 in the year 2016-17 with Rs. 13088.26 lakh working capital and 4288 number of members.

There are also primary agricultural credit societies and mini banks which are operating at village/gram panchayat level. In 2016-17, there were 198 Agricultural Credit co-operative Societies operating in the district having Rs. 8273.33 lakh working capital and 1,85,735 number of members. Further there is the existence of General Insurance Corporation of India and offices of LIC in this district. The lead bank is providing training on entrepreneurship development and also providing training on maintaining records of SHGs in this district.

\subsubsection{Education}

Education is an important input for human resource development. Improvement in awareness and skill is possible only through education in various areas. During 2016-17, there were 1,241 primary schools with $1,68,690$ enrolment and 3,028 teachers. During the same period, the number of upper primary schools was 551 with 59,530 enrolment and 2089 teachers. There were 326 high schools with 71,154 enrolment and 2,701 teachers. While there was one primary school (formal) for every 2.88 sq. $\mathrm{km}$. area with teacher pupil ratio of 1:51 in 2016-17. The district has also one central school and one convent school situated at Puri. The district is committed to Universalisation of Elementary Education (UEE) with a view to attaining millennium goal.

The district has One Sanskrit university (Sri vihar University) and 36 general colleges including 4 govt. colleges ( 2 at Degree level and 2 at +2 level) with 15,739 enrolment and 838 teachers in 2016-17. In the field of technical education, the district has one Govt. Industrial Training Institute and one Engineering College under private management. In the field of medical science, the district has one Ayurvedic College in the Govt. sector and one pharmacy college in the private sector. There is also provision for master's degree courses in computer application (MCA). Recently, there is going to be established a world class private university which is known as Vedanta University in this district.

\subsubsection{Health \& Family Welfare}

Adequate health care and easy access to health services is indispensable for overall human development. State Government have been making sincere efforts to provide adequate health care services to the people within reasonable distance from human habitations. The medical facilities are provided by multiplicity of agencies like Government, local bodies, voluntary organisations and private individuals.

In addition to one Allopathic hospital, there are 11 dispensaries, 9 community health centres and 41 primary healthcentres (PHC) at the end of 201617 in Puri district. So in total there were 62 allopathic medical institutions with 532 bed facilities. Further, there were 16 homoeopathic dispensaries and 23 ayurvedic dispensaries as well as one hospital with 80 bed facilities in the district by the end of 2016-17. About 17.41 lakh patients were treated in all the medical institutions in the district. The number of population sterilised during 2011-12 was 1,426 which increased to 4,863during 2016-17. The details can be shown in Table -1.11 
Table-1.11

Sterilisation of Individuals in Puri District.

\begin{tabular}{|l|l|c|c|}
\hline \multirow{2}{*}{ Sl. No. } & \multicolumn{1}{|c|}{ Items } & \multicolumn{2}{c|}{ Magnitude (in number) } \\
\cline { 3 - 4 } & & $\mathbf{2 0 0 1 - 0 2}$ & $\mathbf{2 0 0 6 - 0 7}$ \\
\hline 1. & Sterilisation & 1,426 & 4,863 \\
\hline 2. & I.U.D. & 5,744 & 5,410 \\
\hline 3. & CC users & 5,978 & 8,866 \\
\hline 4. & Oral Pill users & 3,788 & 5,883 \\
\hline 5. & T.T. for Pregnant & 33,737 & 28,659 \\
\hline 6. & D.P.T. & 29,716 & 27,877 \\
\hline 7. & Polio & 29,716 & 27,871 \\
\hline 8. & BCG & 31,951 & 28,883 \\
\hline 9. & Measles & 24,902 & 27,577 \\
\hline
\end{tabular}
Source - Director of Family Welfare,Odisha.

The birth rate and infant mortality rate which were 17.84 and 27 respectively during 2012 have further declined to 14.89 and 24 by the end of 2017

\subsection{EMPLOYMENT}

With the increase in population and the consequent addition to the labour force, supply of labour continues to outstrip demand resulting in increase in levels of unemployment and underemployment. The occupational classification, based on 2011 census shows that the total workers in the district has been 451 thousand constituting 30\% of the total population of the district. Out of total workers, Main workers are 374 thousand which accounted for $82.9 \%$ and marginal workers of 77 thousand which accounted for $17.1 \%$. The proportion of male workers to male population and female workers to female population in 2001 stood at $51.59 \%$ and $7.67 \%$ respectively which is less than the state average $52.5 \%$ and $24.7 \%$ respectively. This shows that work participation rate among female is lower in the state in general and Puri district in particular.
Growing unemployment is one of the burning problems of the district. In addition to it, educated unemployment is also increasing day by day. The live Register maintained by Directorate of Employment Exchanges shows that there were 29,408 job seekers in the district by the end of 2017 . Out of these, 24,822 were educated unemployed i.e. having qualification matric and above. So, out of the 24,822 educated unemployed, 7,060 were women, 4,935 S.C.and 75 S.T. So unemployment is a burning problem in the district and it should be eradicated by engaging the unemployed in certain income generating activities through SHGs.

\subsection{INCOME}

Income is another indicator of economic development. Due to lack of industrialization, most of the people depend upon agriculture for their livelihood. They are engaged either as skilled labourer, agricultural field labourers or other agricultural labourers. The average daily wages of different classes of rural labourer in 2016-17 was given below.

Table-1.12

Average Daily Wages of Different Classes of Rural Labourer inPuri District

\begin{tabular}{|l|l|c|}
\hline \multicolumn{2}{|c|}{ Types of rural Labourers } & \multicolumn{1}{|c|}{$\begin{array}{c}\text { Average Daily Wages per } \\
\text { Manday( in Rs) }\end{array}$} \\
\hline \multirow{2}{*}{ A) Skilled Labourer } & 1. Carpenter & 132.21 \\
\cline { 2 - 3 } & 2. Masson & 133.40 \\
\cline { 2 - 3 } & 3.Tractor Driver & 118.93 \\
\hline \multirow{2}{*}{ B)Agricultural Field Labourers } & 1. Men & 68.83 \\
\cline { 2 - 3 } & 2. Women & 55.19 \\
\hline C)Other Agricultural Labourers & 1. Men & 78.16 \\
\cline { 2 - 3 } & 2.Women & 44.13 \\
\hline
\end{tabular}

Source - Directorate of Economics \& Statistics, BBSR.Odisha

Thus it is very difficult on the part of the people of the district to maintain their body and soul together. 


\subsection{WORKING OF MICROFINANCE IN THE DISTRICT}

The micro finance way of credit delivery took shape in the district mainly after super cyclone in 1999. The NGOs who were involved in the relief/ rehabilitation of the cyclone affected people introduced the concept of Self Help Group. The initial mindset was to float SHGs for seeking governmental assistance. The efficacy of group dynamics was fully discovered \& sphere of activities got widened after intervention by NABARD \& Mission Shakti. The NGOs like Action Aid, SWAD and UNDP etc who had pioneered for social mobilization of poor gradually started financing the SHGs from their own fund either as grant or as loan.

\subsection{CONCLUSION}

From the above discussion it is concluded that the district is rich in natural resources. The agroclimatic condition and topography are also favourable for exploitation of natural resources. However, the fragmented holding and insufficient irrigational facilities are the main obstacles for agricultural development. Modern methods of farming, adoption of large scale farm mechanism could not pick up to the desired extent due to the fragmentation of land holdings. Agriculture is the predominant sector but has remained stagnant. On the other hand, there is dearth of industries in the district. Though there is the existence of some small scale and cottage industries in the district, these industries are traditional in nature. They are not equipped with advanced technology. Due to lack of mines and mineral ores, no heavy or large scale industry can be established till date. The district famous for its piligrimage has not earned any industrial or commercial importance. The Sun temple of Konark, famous Jagannath temple and Sea beach of Puri are the main tourist attraction places. Thus tourism is an expanding and vibrant sector. But it is not sufficient to absorb the growing population. To absorb the growing population and for improving the standard of living , large number of employment opportunities has to be created with Government encouragement and Mission Shakti Programme initiatives. So Self Help Groups are the need of the hour for widening the livelihood options among the rural people, particularly women.

The analysis of the socio-economic backdrop of the district presents a gloomy scenario. The district is characterized by low income, mass poverty, higher magnitude of unemployment, low human and social development. The picture of the district in terms of some of the macro indicators is much worse than that of the other districts. The district still primarily depends upon agriculture for livelihood and employment. It is industrially backward with nominal industrial units, poor absorption of labour force, and low level of investment and output. Thus, the district needs a significant change in the direction and content through diversification of the structure of its economy. 